\title{
Begonia limprichtii Irmsch. (Begoniaceae) - a new record for India
}

\author{
Dipankar Borah ${ }^{1 *}$, Momang Taram ${ }^{2} \&$ Eric Wahlsteen ${ }^{3}$
}

${ }^{1}$ Department of Botany, Goalpara College, Assam India; ORCID: https:// https://orcid.org/0000-0002-3016-1070

${ }^{2}$ Department of Botany, Rajiv Gandhi University, Arunachal Pradesh India; ORCID: https://orcid.org/0000-0002-4669-615X

${ }^{3}$ Botanical Museum, Lund University, Lund Sweden; ORCID: https:// https://orcid.org/0000-0001-8283-1112

* corresponding author (e-mail: dipankar.borah@goalparacollege.ac.in)

\begin{abstract}
Begonia limprichtii (Begoniaceae) is reported from India for the first time. It belongs to the section Platycentrum and is similar to $B$. thomsonii, but is overall less hairy with ovary nearly glabrous (versus villous) and upper ovary wing beaked and rounded (versus triangular).
\end{abstract}

Key words: Himalaya, Begonia thomsonii, new addition, flora of India

\section{Introduction}

Begonia L. is one of the largest angiosperm genera with currently 2000 accepted species (Hughes et al. 2015). The North Eastern region of India is so far represented by a total of 39 species of Begonia, falling under four different sections (Begonia sect. Diploclinium (Lind1.) A.DC., sect. Parvibegonia A.DC., sect. Platycentrum (Klotzsch) A.DC. and sect. Monophyllon A.DC.) (Camfield \& Hughes 2018; Taram et al. 2020). The species we report here as new for India belongs to the section Platycentrum, the most species-rich section in the region. The section Platycentrum is easily recognized by dehiscent, 2-locular capsules with extended upper wing and smaller lateral wings. They are monecious with rhizomatous habit and often with upright stem. This section is distributed from Nepal eastwards into China and southwards to Sumatra and Java and comprises about 192 species. Phylogenetically, the section is close to the section Diploclinium, with about 107 species in East Asia, from which Platycentrum differs in 2-locular ovary (versus 3-locular), connective extended (versus not extended) and rhizomatous habit (versus usually tuberous).

The eastern Himalaya, including Myanmar, is a cradle for the genus Begonia, in which new species are constantly discovered (e.g Wahlsteen 2018, 2019, 2021; in review; Taram et al. 2020) and several more are to be described. While conducting routine field trips to different districts of Arunachal Pradesh, Northeast India, the authors collected several interesting specimens of Begonia. Amongst them, one named Begonia oyuniae Taram \& N.Krishna (Taram et al. 2020) and many others currently in press. One interesting specimen collected in Komkar, Upper Siang district, was found to be $B e$ gonia limprichtii Irmsch., a species not recorded from India. Its taxonomic status was established after critical evaluation of relevant literature (Clarke 1879; Gu et al. 2007; Camfield \& Hughes 2018) and type materials were deposited in different herbaria (CAL, ASSAM, $\mathrm{K}, \mathrm{E}, \mathrm{PE}$ ). The acronyms of herbaria mentioned in this work are according to http://sweetgum.nybg.org/science /ih/.

\section{Begonia limprichtii Irmsch.}

Repert. Spec. Nov. Regni Veg. Beih. 12:440 (1992) A ff in ity: It is similar to Begonia thomsonii A.DC. but differs in puberulent stipules (versus villous), upper surface of lamina sparsely strigose (versus densely hairy), peduncle with some long hairs (versus densely villous), ovary nearly glabrous (versus villous), upper ovary wing beaked and rounded (versus triangular) and lamina shorter relative to width, abruptly tapering 


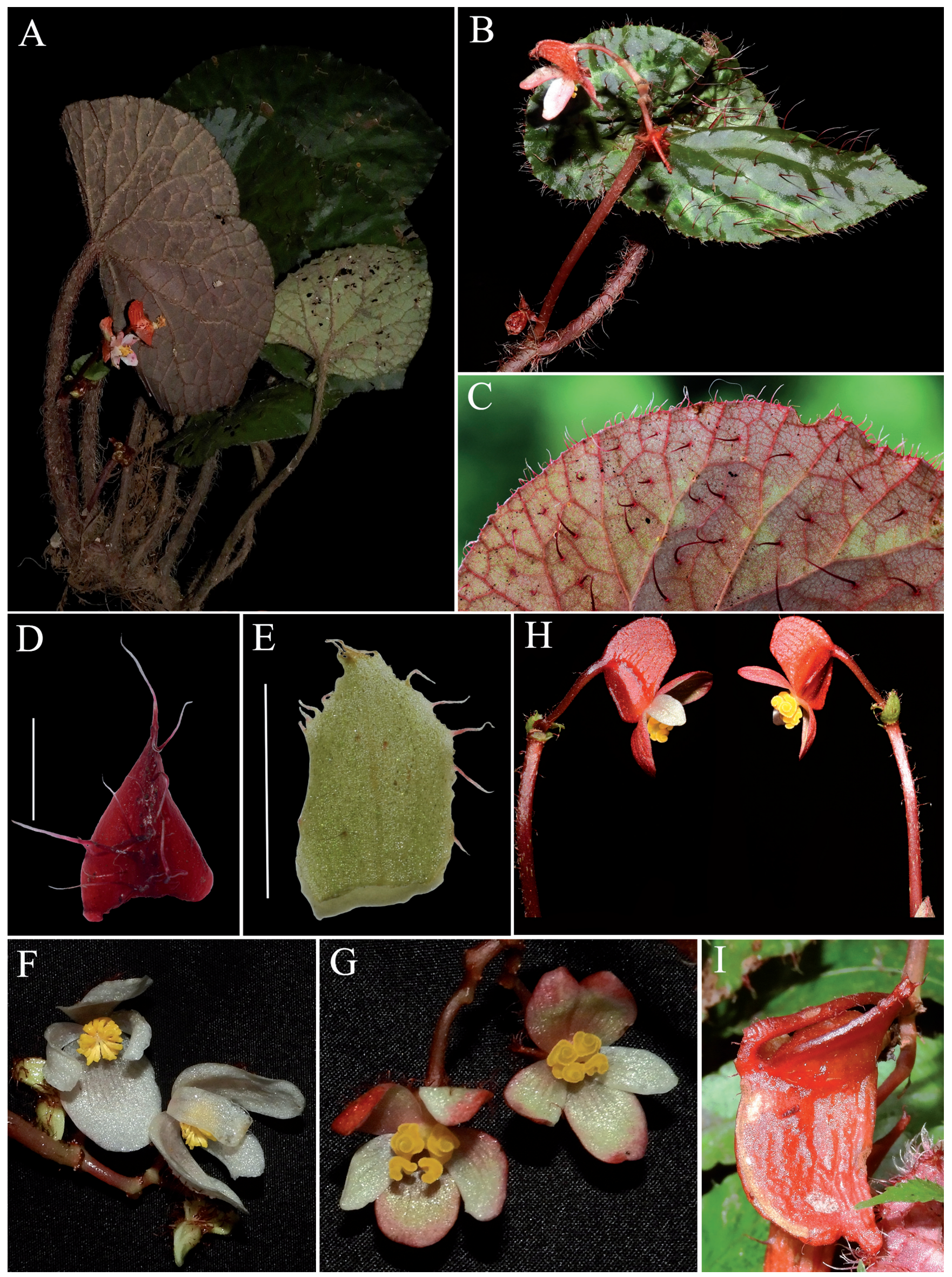

Fig. 1. Begonia limprichtii Irmsch.

Explanations: A - habit, B - leaf adaxial surface, C - leaf abaxial surface, D - stipule, E - bract, F - male flowers, $\mathrm{G}$ - female flower, $\mathrm{H}$ - side view of female flowers showing ovary, I - fruit (A, B, F, G, I by M.Taram; C, D, E, H by D. Borah) 
(versus lamina longer relative to width, acuminate tapering). It differs from $B$. forrestii Irmsch. in stipule margin with strigose hairs and puberulent outer surface (versus glabrous), lamina with long, strigose hairs (versus sparsely hispidulous), anthers oblanceolate (versus obovoid-globose) and ovary nearly glabrous (versus sparsely villous).

Description: Evergreen, perennial rhizomatous monoecious herb, 10-15 cm high. Rhizome 5-6 mm in diameter. Roots fibrous, $20-25 \mathrm{~cm}$ long. Leaves alternate; stipules ovate subulate, $0.9-1.2 \times 0.6-0.8 \mathrm{~cm}$, margin irregular with short strigose hairs, apex acuminate, outer surface puberulent, inner surface glabrous; petiole terete, red, densely villous, $6-16 \times 0.4-0.8 \mathrm{~cm}$; lamina orbicular to widely ovate to orbicular ovate $6-14 \times 3.5-13 \mathrm{~cm}$, margin serrate, apex acute, base cordate, basal lobes overlapping or nearly so, sparsely covered with red strigose hairs 1-2 mm long; venation palmate, veins 6-7. Inflorescence axillary, 5-8 flowers per inflorescence, bracteate, bracts opposite 0.6-1.2 $\times$ 0.3-0.6 cm, ovate to ovate oblong, margin entire to serrate, apex acute to acuminate, inner surface glabrous, outer surface strigose; peduncle terete, red, hairy, $5-10 \times 0.2-0.4 \mathrm{~cm}$. Flowers monoecious. Staminate flower: pedicel 0.9-1.2 cm, white; tepals 4; outer tepals
1.1-1.4 $\times 0.6-0.9 \mathrm{~cm}$, outer surface puberulent, inner surface glabrous, margin entire; inner tepals 1-1.3 $\times$ 0.2-0.4 cm, glabrous on both sides, stamens 30-50, filament $0.5 \mathrm{~mm}$ across, anther $2 \mathrm{~mm}$, oblanceolate. Pistillate flower: pedicel $0.8-1 \mathrm{~cm}$, tepals 4-5, 0.8-1.4 $\times$ 0.4-0.8 cm, reddish white, ovate rounded to ovate oblong, margin entire, outer surface puberulent, inner surface glabrous, apex rounded; style 2-divided from middle, 0.1-0.3 cm, yellow; stigma 2-3-lobed, yellow; ovary 2-locular, nearly glabrous with only few long hairs, 3-winged, smaller wing 0.4-0.6 cm long, longer wing 0.9-1.5 cm long, beaked, rounded. Capsule not observed (Fig. 1).

Distribution, ecology and phenology: Begonia limprichtii has been previously known from Sichuan and Yunnan in China. However, informal reports of the species occurrence in Arunachal Pradesh were presented by Morris $(2010,2016)$ and discussed by Camfield and Hughes (2018, p. 105), so this finding was just a matter of time. $B$. limprichtii prefers moist and shady habitats, growing in cracks and crevices near ephemeral and perennial streams in tropical evergreen forests (Fig. 2), at an elevation of 200-400 m a.s.1., in

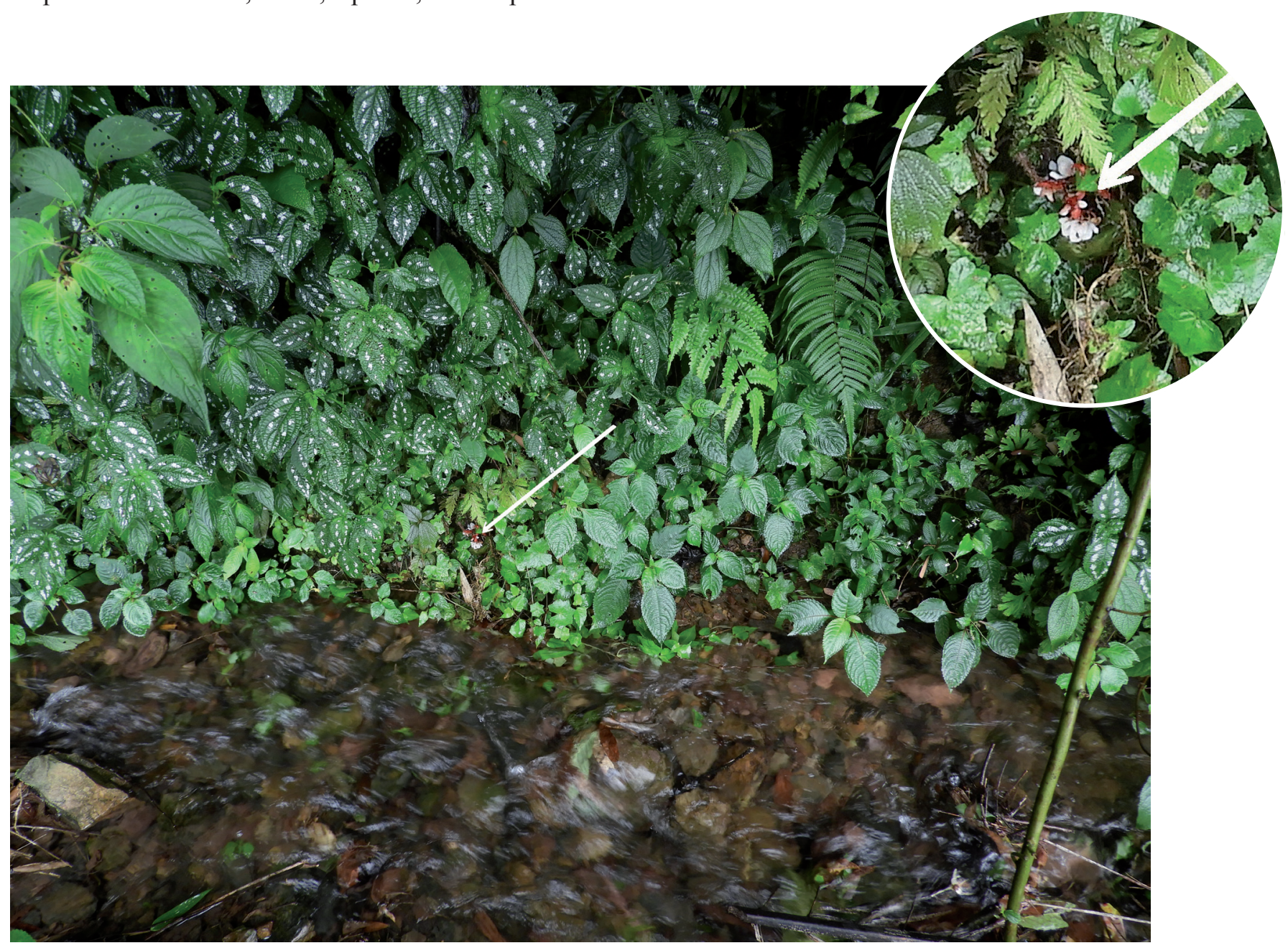

Fig. 2. Begonia limprichtii Irmsch. - habitat (photograph by M. Taram) 


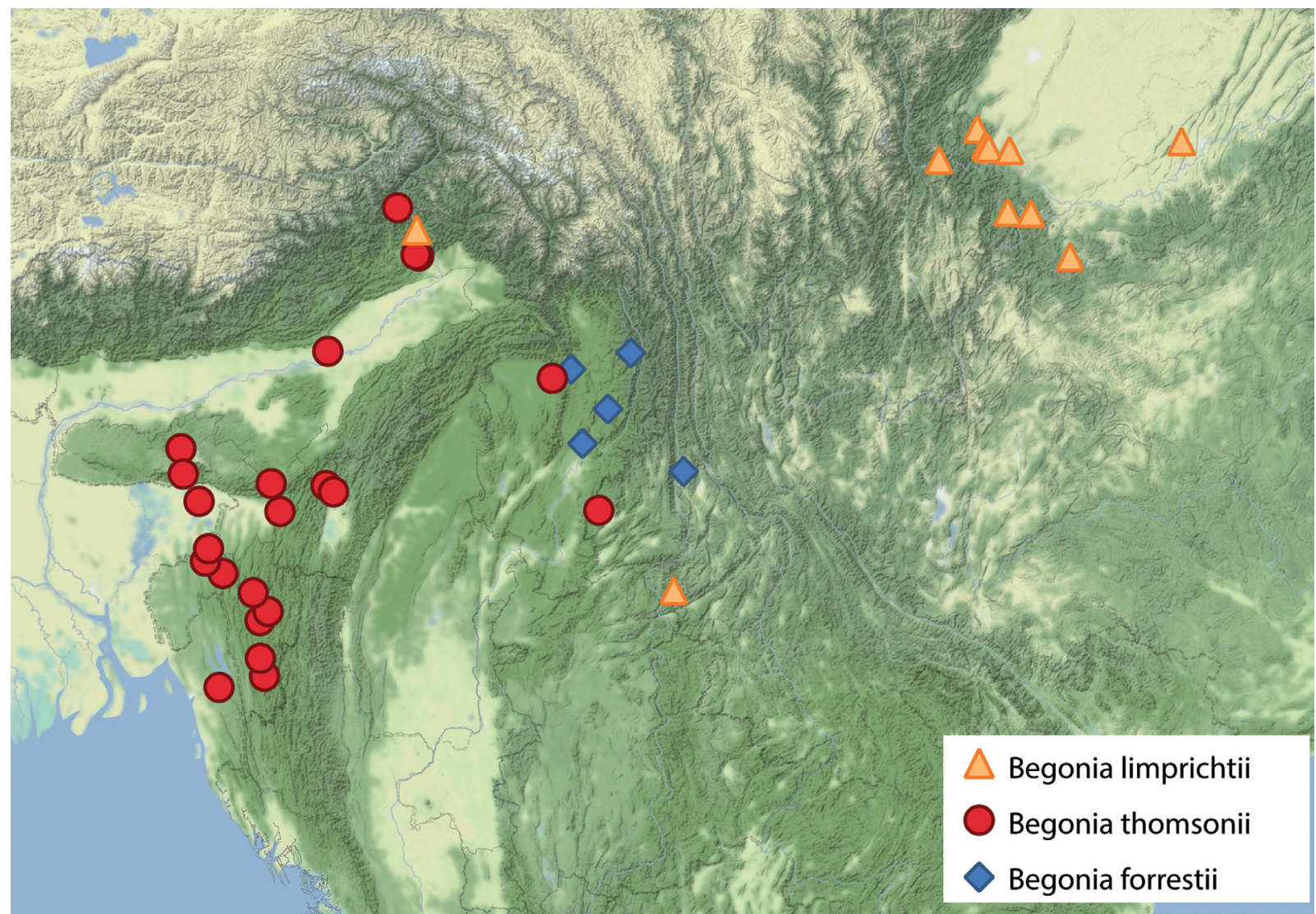

Fig. 3. Distribution map of Begonia limprichtii, B. forrestii and B. thomsonii

association with Henckelia pumila (D.Don) A. Dietr., Lysionotus D. Don sp., Begonia palmata D.Don, Begonia griffithiana (A.DC.) Warb., Sonerilla sp., Nephrolepis cordifolia (L.) C.Presl, Angiopteris Hoffm. sp., Pilea Lindl. sp., etc. Flowering starts in May and continues until June.

Proposed IUCN conservation status: Data Deficient (DD). In India this species occurs in the Upper Siang district of Arunachal Pradesh, where the opportunities for rigorous botanical survey work are limited and do not allow to assess its proper status.

Specimen examined: India, Arunachal Pradesh, Upper Siang district, Komkar, 400 m a.s.1., 02 VI 2019, M. Taram 310 (CAL) (Fig. 3).

\section{Key to closely related species of Begonia in Indo-Burma}

1 - Stipules glabrous, lamina sparely hispidulous, leaf apex rounded, obtuse, rhizome moniliform

B. forrestii
$1^{*}$ - Stipules hairy, lamina with long red hairs, leaf apex attenuate, rhizome linear ........................................2 2 - Stipules villous, lamina upper surface densely villous, upper ovary wing triangular ............. thomsonii $2 *$-Stipules puberulent, lamina upper surface strigose, upper ovary wing beaked and rounded ....B. limprichtii

Acknowledgments. We are thankful to Mr. Ojar Taku, Oyem Taram and Olom Tosung for their help and support in the field. The authors are also thankful to the Goalpara College and Rajiv Gandhi University for providing necessary facilities.

\section{Author Contributions}

Research concept and design: M. Taram

Acquisition and/or assembly of data: D. Borah

Data analysis and interpretation: E. Wahlsteen

Drafting the article: D. Borah

Critical revision: D. Borah, E. Wahlsteen

Final approval: D. Borah, E. Wahlsteen, M. Taram 


\section{References}

Campield R. \& Hughes M. 2018. A revision and one new species of Begonia L. (Begoniaceae, Cucurbitales) in Northeast India. European Journal of Taxonomy 396: 1-116. https://doi.org/10.5852/ejt.2018.396

Clarke C. B. 1879. Begoniaceae. In: J. D. Hooker (ed.). Flora of British India, vol. 2, pp. 636-656. London.

Gu C., Peng C. \& Turland N. 2007. Begoniaceae. In: Z. Wu \& P. RAVEn (eds.). Flora of China, pp. 153-207.

Hughes M., Moonlight P. W., Jara A. \& Pullan M. 2015. Begonia Resource Centre. http://padme.rbge.org.uk/ begonia. Accessed 25 Oct 2019.

Iucn Standards and Petitions Subcommittee. 2017. Guidelines for Using the IUCN Red List Categories and Criteria. Version 13. Prepared by the Standards and Petitions Subcommittee

Moonlight P. W., Ardi W. H., Padilla L. A., Chung K. F., Fuller D., Girmansyah D., Hollands R. Jara-Muñoz A. Kiew R. Leong W.-Ch., Liu Y., Mahardika A., Marasinghe L. D. K., O’Connor M., Peng Ch.-I. Pérez Á. J., Phutthai T., Pullan M., Rajbhandary S., Reynel C., Rubite R. R., Sang J., Scherberich D., Shui Y.-M., Tebiitt M. C., Thomas D. C., Wilson H. P., Zaini N. H. \& Hughes M. 2018. Dividing and conquering the fastest-growing genus: Towards a natural sectional classification of the mega-diverse genus Begonia (Begoniaceae). Taxon 67(2): 267-323. https://doi.org/10.12705/672.3

Morris R. 2010. A "new” Begonia species from India. The Begonian 77: 214-218.

Morris R. 2016. Species Begonias of the Eastern Himalayas of Arunachal, India. Leslie C. Koo, Taiwan.

Taram M., Borah D., Krishna N., Pradeep A. K., Amrutha A. \& Hughes M. 2020. Begonia oyuniae (Begonia sect. Monophyllon, Begoniaceae), a remarkable new species from Northeast India. Garden's Bulletin Singapore 72(1): 109-115. doi: 10.26492/gbs72(1).2020-10

Wahlsteen E. 2018. Begonia mariachristinae (Begoniaceae), a new species from northern Myanmar. Edinburgh Journal of Botany 75(2): 161-166. https:/doi. org/10.1017/S0960428618000021

Wahlsteen E. 2019. A new species of Begonia L. (Begoniaceae) and some notes on Begonia difformis from Kachin, northern Myanmar. Phytotaxa 420(3): 241248. https://doi.org/10.11646/phytotaxa.420.3.4

WAHLSteEn E. 2021. Synonymization of Begonia putaoensis (Begoniaceae) with Begonia dicressine. Phytotaxa 480(1): 91-93. https://doi.org/10.11646/phytotaxa. 480.1 .9 